\title{
Pengaruh Minat Belajar Terhadap Hasil Belajar Peserta Didik Pada Mata Pelajaran Bahasa Arab di MIS Ma'arif Ambopadang Kecamatan Tubbi Taramanu Kabupaten Polewali Mandar
}

\author{
Hasrati $^{1}$, Nur Afiah ${ }^{2}$, Yulmiati $^{3}$ \\ ${ }^{1,2,3}$ Institut Agama Islam DDI Polewali Mandar, Sulawesi Barat \\ 1email: hasrati@ddipolman.ac.id \\ 2 email: nurafiah@ddipolman.ac.id \\ 3 email: yulmiati@ddipolman.ac.id
}

\begin{abstract}
Abstrak
Tujuan penelitian ini adalah 1) untuk mengetahui minat belajar peserta didik terhadap mata pelajaran bahasa Arab pada MIS Ma'arif Ambopadang Kecamatan Tubbi Taramanu Kabupaten Polewali Mandar; 2) Untuk mengetahui apakah ada pengaruh minat belajar terhadap hasil belajar peserta didik mata pelajaran bahasa Arab pada MIS Ma'arif Ambopadang Kecamatan Tubbi Taramanu Kabupaten Polewali Mandar, Sulawesi Barat, Indonesia. Penelitian dilakukan secara kuantitatif dengan teknik Simple Random Sampling tahun ajaran 2020. Sumber data adalah kepala Madrasah, guru mata pelajaran Bahasa Arab dan peserta didik di MIS Ma'arif Ambopadang Kecamatan Tubbi Taramanu. Data dikumpulkan dengan menggunakan instrument 1) Obsevasi 2) Angket atau kuesioner3) Tes 4) Dokumentasi. Hasil perhitungan dengan menggunakan rumus korelasi diperoleh $r_{\text {hitung }}=0,520$. Kemudian hasil tersebut dibandingkan dengan $r_{\text {tabel }}$ dengan $\mathrm{df}=18$ dengan taraf signifikan $5 \%(0,520>0,468)$ dan taraf sinifikasi $1 \%(0,520>0,01)$. Dengan demikian dapat diketahui bahwa hipotesis nihil (Ho) ditolak sedangkan hipotesis alternatif (Ha) diterima. Perhitungan ini menunjukkan terdapat pengaruh yang signifikan antara minat belajar dan hasil belajar peserta didik pada mata pelajaran bahasa Arab dengan koefisien determinan sebesar 27,04\%. Disimpulkan bahwa minat belajar peserta didik pada mata pelajaran bahasa Arab tergolong cukup baik dan minat belajar memiliki pengaruh yang sedang/cukup terhadap hasil belajar peserta didik pada mata pelajaran bahasa Arab.
\end{abstract}

Kata Kunci: Minat Belajar, Hasil Belajar, Mata Pelajaran Bahasa Arab

\begin{abstract}
The purposes of this study were 1) to determine the students' learning interest in Arabic subjects at MIS Ma'arif Ambopadang, Tubbi Taramanu District, Polewali Mandar Regency; 2) To find out whether there is an influence of interest in learning on the learning outcomes of students in Arabic subjects at MIS Ma'arif Ambopadang, Tubbi Taramanu District, Polewali Mandar Regency, West Sulawesi, Indonesia. The research was conducted quantitatively using the Simple Random Sampling technique for the 2020 academic year. The data sources were the head of the Madrasah, Arabic language teachers and students at MIS Ma'arif Ambopadang, Tubbi Taramanu District. Data were collected using the instrument 1) Observation 2) Questionnaire or questionnaire 3) Test 4) Documentation. The results of calculations using the correlation formula obtained rcount $=0.520$. Then these results were compared with the rtable with $\mathrm{df}=18$ with a significant level of $5 \%(0.5200 .468)$ and a $1 \%$ sinification level $(0.520>0.01)$. Thus it can be seen that the null hypothesis (Ho) is rejected while the alternative hypothesis (Ha) is accepted. The calculation shows that there is a significant influence between learning interest and student learning outcomes in Arabic subjects with a determinant coefficient of 27.04\%. It was concluded that students' interest in learning in Arabic subjects was quite good and interest in learning had a moderate/sufficient influence on student learning outcomes in Arabic subjects.
\end{abstract}

Keywords: Interest in Learning, Learning Outcomes, Arabic Subjects 


\section{Loghat Arabi: Jurnal Bahasa Arab dan Pendidikan Bahasa Arab}

\section{Pendahuluan}

Pembelajaran Bahasa Arab memiliki peran yang sangat penting dalam dalam Islam. Kemampuan Bahasa Arab bagi umat Islam berfungsi sebagai alat dasar untuk memahami dan menerapkan nilai-nilai Islam. Hal ini disebabkan oleh karena adanya keterikatan antara pembelajaran Bahasa Arab dan Pembelajaran Islam ${ }^{1}$. Karena sumber pengetahuan Islam yaitu nilai-nilai Islam ada dalam al-Qur'an dan Sunnah, keduanya akan dapat difahami dengan baik melalui bahasa Arab. ${ }^{2}$ Bahasa Arab memiliki kaitan yang sangat erat dengan agama Islam, karena semua ajaran Islam terhimpun dalam al-Qur'an dan dilengkapi dengan penjelasan alHadis. Untuk dapat mengkaji dan mendalami ajaran agama Islam harus mempelajari alQur'an dan al-Hadis. Selanjutnya, agar dapat mempelajari al-Qur'an dan al-Hadis dibutuhkan kemampuan berbahasa Arab. Terlebih lagi, Bahasa Arab merupakan bahasa "penyelamat" pendidikan Islam, tanpa bahasa Arab pendidikan Islam akan mengalami kepunahan (kebinasaan). ${ }^{3}$

Pembelajaran Bahasa dalam kaitannya dengan perbuatan belajar dan hasil belajar merupakan suatu kegiatan yang saling berhubungan. Belajar juga diartikan sebagai proses mengasimilasikan dan menghubungkan pengalaman atau bahan yang sudah dipelajari sebelumnya sehingga pengertiannya bisa dikembangkan. Proses tersebut bercirikan: a) belajar berarti membentuk makna, b) belajar bukanlah kegiatan mengumpulkan fakta melainkan lebih suatu pengembangan pemikiran dengan membuat pemikiran yang baru, c) proses belajar yang sebenarnya adalah pada saat terjadi tidak keseimbangan (disequilibrium). ${ }^{4}$ Artinya peserta didik tidak akan menghasilkan hasil belajar yang baik jika tidak disertai dengan perbuatan belajarnya. Jadi, hasil belajar peserta didik tercermin dari perbuatan belajarnya. Akan tetapi, untuk mencapai hasil belajar yang baik, peserta didik haruslah berusaha mengatasi faktorfaktor yang dapat mempengaruhinya.

\footnotetext{
${ }^{1}$ Ritonga, Mahyudin, Hendro Widodo, and Talqis Nurdianto. "Arabic language learning reconstruction as a response to strengthen Al-Islam studies at higher education." Studies at Higher Education (January 23, 2021). International Journal of Evaluation and Research in Education (IJERE) 10.1 (2021): 355-363. https://papers.ssrn.com/sol3/papers.cfm?abstract_id=3791177

2 Akmaliyah, Akmaliyah, et al. "Child-Friendly Teaching Approach for Arabic Language in Indonesian Islamic Boarding School." International Journal of Language Education 5.1 (2021): 501-514. https://ojs.unm.ac.id/ijole/article/view/15297

${ }^{3}$ Munawarah, Munawarah, and Zulkiflih Zulkiflih. "Pembelajaran Keterampilan Menulis (Maharah alKitabah) dalam Bahasa Arab." Loghat Arabi: Jurnal Bahasa Arab dan Pendidikan Bahasa Arab 1.2 (2021): 2234. https://journal.iaiddipolman.ac.id/index.php/loghat/article/view/15

4 Hamzah, Hamzah. "KONSTRUKTIVISME DAN IMPLIKASINYA DALAM PEMBELAJARAN BAHASA ARAB." Prosiding Konferensi Nasional Bahasa Arab 4.4 (2018): 117-128. http://prosiding.arabum.com/index.php/konasbara/article/view/262
} 


\section{Loghat Arabi: Jurnal Bahasa Arab dan Pendidikan Bahasa Arab}

Salah satu faktor yang dapat mempengaruhi minat belajar dan dan hasil bealajar pada pembelajaran bahasa adalah sistem pembelajaran bahasa Arab itu sendiri. Pembelajaran bahasa Arab dikritik karena monoton, tradisional, dan tidak inovatif dibandingkan dengan pembelajaran bahasa lainnya. Hal ini dikarenakan absolutisme dan kurangnya kreativitas pemangku pembelajaran bahasa Arab (dosen, guru, kiai) untuk menerapkan metode dan media pembelajaran bahasa Arab yang sesuai dengan kemajuan teknologi informasi. ${ }^{5}$ Media yang tepat, metode yang baik, dan kompetensi seorang pendidik menjadi faktor penentu keberhasilan sebuah proses pembelajaran. ${ }^{6}$

Hal lain yang dapat mempengaruhi hasil belajar suatu pembelajaran, di antaranya adalah minat yang merupakan hal yang penting. Minat merupakan pendorong yang menyebabkan seseorang memberikan perhatiannya terhadap seseorang atau suatu aktifitas tertentu seperti pembelajaran bahasa Arab. Minat berlajar siswa berhubungan dengan hasil belajar bahasa Arab. Sebab, hasil belajar Bahasa Arab dapat ditingkatkan melalui motivasi dan minat belajar siswa. ${ }^{7}$

Minat belajar juga bergantung pada faktor-faktor lainnya seperti perhatian, keingintahuan, motivasi ${ }^{8}$, kebutuhan, dan lain-lainnya. Minat belajar juga dapat mempengaruhi keadaan pencapaian prestasi seorang peserta didik dalam proses pembelajaran. Misalnya seseorang peserta didik menaruh minat besar terhadap mata pelajaran bahasa Arab maka akan memusatkan perhatiannya lebih banyak dari pada peserta didik lainnya. Pemusatan perhatian yang intensif tersebut memungkinkannya untuk belajar giat, dan akhirnya mencapai prestasi yang diinginkannya. Guru dalam kaitan ini seyogyanya berusaha membangkitkan minat belajar peserta didik untuk menguasai bidang studi dengan cara yang baik, bermanfaat,

\footnotetext{
${ }^{5}$ Nugrawiyati, Jepri. "Media Audio-Visual dalam Pembelajaran Bahasa Arab." El-Wasathiya: Jurnal

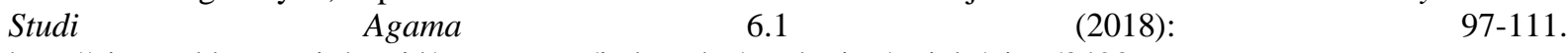
http://ejournal.kopertais4.or.id/mataraman/index.php/washatiya/article/view/3420

${ }^{6}$ Mustafa, Mustafa. "Dinamika Metode Pembelajaran Bahasa Arab." Loghat Arabi: Jurnal Bahasa $\begin{array}{llllll}\text { Arab dan } & \text { Pendidikan } & \text { Bahasa } & \text { Arab } & 1.2 & \text { (2021): }\end{array}$ https://journal.iaiddipolman.ac.id/index.php/loghat/article/view/17

${ }^{7}$ AH, Hanifal Fauzy, Zainal Abidin Arief, and Muhyani Muhyani. "Strategi motivasi belajar dan minat belajar dengan hasil belajar Bahasa Arab." Tawazun: Jurnal Pendidikan Islam 12.1 (2019): 112-127. http://ejournal.uika-bogor.ac.id/index.php/TAWAZUN/article/view/1843

${ }^{8}$ Putri, Wakhidati Nurrohmah. "Pengaruh Media Pembelajaran Terhadap Motivasi Belajar Bahasa Arab Siswa Madrasah Tsanawiyah." LISANIA: Journal of Arabic Education and Literature 1.1 (2017): 1-16. https://ijtihad.iainsalatiga.ac.id/index.php/lisania/article/view/1160/0
} 


\section{Loghat Arabi: Jurnal Bahasa Arab dan Pendidikan Bahasa Arab}

dan sesuai dengan harapan yang ingin dicapai ${ }^{9}$ melalui pembelajaran efektif dalam pengajaran bahasa Arab. ${ }^{10}$

Identifikasi masalah yang penulis perleh melalui pra-observasi di MIS Ma'arif Ambopadang Kecamatan Tubbi Taramanu Kabupaten Polewali Mandar adalah: 1) Kurangnya minat belajar peserta didik terhadap pembelajaran bahasa Arab; 2) Kurangnya rasa hormat peserta didik terhadap guru mata pelajaran bahasa Arab secara personal; 3) Krisis moral pada peserta didik; 4) Proses pembelajaran bahasa Arab tidak efektif; 5) Keadaan kelas yang tidak kondusif; 6) Sarana dan prasarana yang kurang memadai. ${ }^{11}$

Berdasarkan hasil identifikasi masalah melalui pra-observasi yang dilakukan maka tujuan penelitian ini adalah 1) untuk mengetahui minat belajar peserta didik terhadap mata pelajaran bahasa Arab pada MIS Ma'arif Ambopadang Kecamatan Tubbi Taramanu Kabupaten Polewali Mandar; dan 2) untuk mengetahui apakah ada pengaruh minat belajar terhadap hasil belajar peserta didik mata pelajaran bahasa Arab pada MIS Ma'arif Ambopadang Kecamatan Tubbi Taramanu Kabupaten Polewali Mandar.

\section{Metode Penelitian}

Jenis penelitian yang digunakan dalam penelitian ini adalah penelitian lapangan (field research). Dari jenis datanya, penelitian ini termasuk penelitian kuantitatif karena data penelitian berupa angka-angka dan analisis secara statistik. Lokus penelitian ini di MIS Ma'arif Ambopadang Kecamatan Tutar, Kabupaten Polewali Mandar. Penelitian ini dilakukan selama kurang lebih tiga bulan, sejak September-Desember 2020.

Adapun teknik sampling yang digunakan adalah Simple Random Sampling. Populasi dalam penelitian ini adalah seluruh peserta didik pada MIS Ma'arif Ambopadang Kecamatan Tubbi Taramanu tahun ajaran 2020 yang berjumlah 60 orang. Dari populasi tersebut, yang dijadikan sampel sebanyak 20 peserta didik.

Variabel dalam penelitian ini adalah:

a. Variabel bebas (Independen Variable) yaitu minat belajar sebagai variabel X

b. Variabel terikat (Dependen Variable) yaitu hasil belajar peserta didik pada mata pelajaran bahasa Arab sebagai variabel Y:

${ }^{9}$ Muhibbin Syah, Psikologi Pendidikan dengan Pendekatan Baru (Cet. IX; Bandung: Remaja Rosda Karya, 2004), h. 136.

${ }^{10}$ Mahmud, Basri, and Hamzah Hamzah. "Pembelajaran Efektif dalam Pengajaran Bahasa Arab Tingkat Menengah." Loghat Arabi: Jurnal Bahasa Arab dan Pendidikan Bahasa Arab 1.1 (2020): 23-36. https://journal.iaiddipolman.ac.id/index.php/loghat/article/view/3

${ }^{11}$ Pra Observasi (Di lakukan pada tanggal 13 Juni 2020) 


\section{Loghat Arabi: Jurnal Bahasa Arab dan Pendidikan Bahasa Arab}

Sumber data dalam penelitian ini adalah kepala Madrasah, guru mata pelajaran Bahasa Arab dan peserta didik di MIS Ma'arif Ambopadang Kecamatan Tubbi Taramanu.

Instrumen yang digunakan dalam penelitian ini adalah angket dan tes yang berupa pertanyaan atau pernyataan. Sehingga, teknik pengumpulan data dalam penelitian ini adalah: 1) Obsevasi: Peneliti mengamati pengaruh minat belajar dan fenomena-fenomena yang berhubungan dengan hasil belajar peserta didik; 2) Angket atau kuesioner: untuk mengukur variabel dalam penelitian ini yaitu menggunakan skala likert dengan skala 4 poin; 3) Tes: Metode pelaksanaan evaluasi atau tes hasil belajar digunakan untuk mengetahui mengetahui dan mengumpulkan data-data tentang hasil belajar bahasa Arab yang dicapai peserta didik di MIS Ma'arif Ambopadang Kecamatan Tubbi Taramanu Kabupaten Polewali Mandar. Evaluasi atau tes hasil belajar ini dilaksanakan dengan menggunakan lembar tes tertulis yang berisi soal-soal bahasa Arab berbentuk pilihan ganda dangan jumlah soal 20 nomor yang bersumber dari buku paket bahasa arab, 4) Dokumentasi: untuk mengumpulkan data sekunder yaitu data tertulis yang memberikan keterangan tentang Visi, Misi, dan tujuan, keadaan Peserta didik, struktur organisasi, dan jumlah guru di MIS Ma'arif Ambopadang Kecamatan Tubbi Taramanu serta dokumen-dokumen lain yang berhubungan dengan penelitian ini.

\section{Hasil Penelitian dan Pembahasan}

Gambaran Minat Belajar Peserta Didik Terhadap Mata Pelajaran Bahasa Arab Pada MIS Ma'arif Ambopadang Kecamatan Tubbi Taramanu Kabupaten Polewali Mandar

Berikut adalah gambaran data tentang minat belajar peserta didik pada MIS Ma'arif Ambopadang Kecamatan Tubbi Taramanu Kabupaten Polewali Mandar yang disajikan dalam bentuk persen.

\begin{tabular}{|c|l|c|c|}
\hline No & \multicolumn{1}{|c|}{ Alternatif Jawaban } & N & Persen (\%) \\
\hline 1 & Selalu & 1 & $5 \%$ \\
\hline 2 & Sering & 11 & $55 \%$ \\
\hline 3 & Kadang-kadang & 6 & $30 \%$ \\
\hline 4 & Tidak pernah & 2 & $10 \%$ \\
\hline \multicolumn{2}{|c|}{ Jumlah } & 20 & $100 \%$ \\
\hline
\end{tabular}

Tabel 1. Cepat datang ke Sekolah jika hari itu ada pelajaran bahasa Arab (angket item 1)

Tabel di atas menunjukkan bahwa 5\% peserta didik selalu datang cepat ke sekolah jika hari itu ada pelajaran bahasa Arab, peserta didik yang menyatakan sering sebanyak 55\%, peserta didik yang menyatakan kadang-kadang sebanyak 30\%, dan peserta didik yang 


\section{Loghat Arabi: Jurnal Bahasa Arab dan Pendidikan Bahasa Arab}

menyatakan tidak pernah sebanyak 10\%. Dari tabel tersebut dapat disimpulkan bahwa siswa sering cepat datang ke Sekolah jika hari itu ada pelajaran bahasa Arab.

\begin{tabular}{|c|l|c|c|}
\hline No & \multicolumn{1}{|c|}{ Alternatif Jawaban } & N & \% \\
\hline 1 & Selalu & 6 & $30 \%$ \\
\hline 2 & Sering & 8 & $40 \%$ \\
\hline 3 & Kadang-kadang & 6 & $30 \%$ \\
\hline 4 & Tidak pernah & - & $0 \%$ \\
\hline \multicolumn{2}{|c|}{ Jumlah } & 20 & $100 \%$ \\
\hline
\end{tabular}

Tabel 2. Membawa buku paket bahasa Arab ketika ada pelajaran bahasa Arab (angket item 2)

Tabel di atas menunjukkan bahwa 30\% peserta didik selalu datang membawa buku paket bahasa Arab ketika ada pelajaran bahasa Arab, peserta didik yang menyatakan sering sebanyak $40 \%$, peserta didik yang menyatakan kadang-kadang sebanyak 30\%, dan peserta didik yang menyatakan tidak pernah sebanyak 0\%. Dari tabel tersebut dapat disimpulkan bahwa siswa sering membawa buku paket bahasa Arab ketika ada pelajaran bahasa Arab.

\begin{tabular}{|c|l|c|c|}
\hline No & Alternatif Jawaban & N & \% \\
\hline 1 & Selalu & - & $0 \%$ \\
\hline 2 & Sering & 12 & $60 \%$ \\
\hline 3 & Kadang-kadang & 8 & $40 \%$ \\
\hline 4 & Tidak pernah & - & $0 \%$ \\
\hline \multicolumn{2}{|c|}{ Jumlah } & 20 & $100 \%$ \\
\hline
\end{tabular}

Tabel 3. Guru mata pelajaran bahasa Arab menyenangkan (angket item 3)

Tabel di atas menunjukkan bahwa $0 \%$ peserta didik menyatakan guru mata pelajaran bahasa Arab selalu menyenangkan, peserta didik yang menyatakan sering sebanyak $60 \%$, peserta didik yang menyatakan kadang-kadang sebanyak 40\%, dan peserta didik yang menyatakan tidak pernah sebanyak 0\%. Dari tabel tersebut dapat disimpulkan bahwa guru mata pelajaran bahasa Arab sering menyenangkan.

\begin{tabular}{|c|l|c|c|}
\hline No & \multicolumn{1}{|c|}{ Alternatif Jawaban } & N & \% \\
\hline 1 & Selalu & 6 & $30 \%$ \\
\hline 2 & Sering & 8 & $40 \%$ \\
\hline 3 & Kadang-kadang & 6 & $30 \%$ \\
\hline 4 & Tidak pernah & - & $0 \%$ \\
\hline \multicolumn{2}{|c|}{ Jumlah } & 20 & $100 \%$ \\
\hline
\end{tabular}

Tabel 4. Betah di kelas ketika pelajaran bahasa Arab berlangsung (angket item 4) 


\section{Loghat Arabi: Jurnal Bahasa Arab dan Pendidikan Bahasa Arab}

Tabel di atas menunjukkan bahwa 30\% peserta didik menyatakan betah di kelas ketika pelajaran bahasa Arab berlangsung, peserta didik yang menyatakan sering sebanyak 40\%, peserta didik yang menyatakan kadang-kadang sebanyak 30\%, dan peserta didik yang menyatakan tidak pernah sebanyak 0\%. Dari tabel tersebut dapat disimpulkan bahwa peserta didik sering betah di kelas ketika pelajaran bahasa Arab berlangsung.

\begin{tabular}{|c|l|c|c|}
\hline No & \multicolumn{1}{|c|}{ Alternatif Jawaban } & N & \% \\
\hline 1 & Selalu & 4 & $20 \%$ \\
\hline 2 & Sering & 3 & $15 \%$ \\
\hline 3 & Kadang-kadang & 7 & $35 \%$ \\
\hline 4 & Tidak pernah & 6 & $30 \%$ \\
\hline \multicolumn{2}{|c|}{ Jumlah } & 20 & $100 \%$ \\
\hline
\end{tabular}

Tabel 5. Duduk di depan ketika pelajaran bahasa Arab berlangsung (angket item 5)

Tabel di atas menunjukkan bahwa $20 \%$ peserta didik menyatakan duduk di depan ketika pelajaran bahasa Arab berlangsung, peserta didik yang menyatakan sering sebanyak $15 \%$, peserta didik yang menyatakan kadang-kadang sebanyak $35 \%$, dan peserta didik yang menyatakan tidak pernah sebanyak 30\%. Dari tabel tersebut dapat disimpulkan bahwa peserta didik kadang-kadang duduk di depan ketika pelajaran bahasa Arab berlangsung.

\begin{tabular}{|c|l|c|c|}
\hline No & \multicolumn{1}{|c|}{ Alternatif Jawaban } & N & \% \\
\hline 1 & Selalu & - & $0 \%$ \\
\hline 2 & Sering & 4 & $20 \%$ \\
\hline 3 & Kadang-kadang & 9 & $45 \%$ \\
\hline 4 & Tidak pernah & 7 & $35 \%$ \\
\hline \multicolumn{2}{|c|}{ Jumlah } & 20 & $100 \%$ \\
\hline
\end{tabular}

Tabel 6. Mengajukan pertanyaan jika tidak mengerti pelajaran bahasa Arab (angket item 6)

Tabel di atas menunjukkan bahwa $0 \%$ peserta didik menyatakan mengajukan pertanyaan jika tidak mengerti pada pelajaran bahasa Arab, peserta didik yang menyatakan sering sebanyak $20 \%$, peserta didik yang menyatakan kadang-kadang sebanyak $45 \%$, dan peserta didik yang menyatakan tidak pernah sebanyak 35\%. Dari tabel tersebut dapat disimpulkan bahwa peserta didik kadang-kadang mengajukan pertanyaan jika tidak mengerti pada pelajaran bahasa Arab.

\begin{tabular}{|c|c|c|c|}
\hline No & \multicolumn{1}{|c|}{ Alternatif Jawaban } & N & \% \\
\hline 1 & Selalu & 7 & $35 \%$ \\
\hline
\end{tabular}




\section{Loghat Arabi: Jurnal Bahasa Arab dan Pendidikan Bahasa Arab}

\begin{tabular}{|c|l|c|c|}
\hline 2 & Sering & 6 & $30 \%$ \\
\hline 3 & Kadang-kadang & 6 & $30 \%$ \\
\hline 4 & Tidak pernah & 1 & $5 \%$ \\
\hline \multicolumn{2}{|c|}{ Jumlah } & 20 & $100 \%$ \\
\hline
\end{tabular}

Tabel 7. Tidak suka diganggu ketika pelajaran bahasa Arab berlangsung (angket item 7)

Tabel di atas menunjukkan bahwa 35\% peserta didik menyatakan tidak suka diganggu ketika pelajaran bahasa Arab berlangsung, peserta didik yang menyatakan sering sebanyak $30 \%$, peserta didik yang menyatakan kadang-kadang sebanyak 30\%, dan peserta didik yang menyatakan tidak pernah sebanyak 5\%. Dari tabel tersebut dapat disimpulkan bahwa peserta didik selalu tidak suka diganggu ketika pelajaran bahasa Arab berlangsung.

\begin{tabular}{|c|l|c|c|}
\hline No & \multicolumn{1}{|c|}{ Alternatif Jawaban } & N & \% \\
\hline 1 & Selalu & - & $0 \%$ \\
\hline 2 & Sering & 10 & $50 \%$ \\
\hline 3 & Kadang-kadang & 5 & $25 \%$ \\
\hline 4 & Tidak pernah & 5 & $25 \%$ \\
\hline \multicolumn{2}{|c|}{ Jumlah } & 20 & $100 \%$ \\
\hline
\end{tabular}

Tabel 8. Konsentrasi mendengar dan memperhatikan penjelasan guru (angket item 8)

Tabel di atas menunjukkan bahwa $0 \%$ peserta didik menyatakan konsentrasi mendengar dan memperhatikan penjelasan guru bahasa Arab, peserta didik yang menyatakan sering sebanyak 50\%, peserta didik yang menyatakan kadang-kadang sebanyak $25 \%$, dan peserta didik yang menyatakan tidak pernah sebanyak 25\%. Dari tabel tersebut dapat disimpulkan bahwa peserta didik sering konsentrasi mendengar dan memperhatikan penjelasan guru bahasa Arab.

\begin{tabular}{|c|l|c|c|}
\hline No & \multicolumn{1}{|c|}{ Alternatif Jawaban } & N & \% \\
\hline 1 & Selalu & 1 & $5 \%$ \\
\hline 2 & Sering & 8 & $40 \%$ \\
\hline 3 & Kadang-kadang & 6 & $30 \%$ \\
\hline 4 & Tidak pernah & 5 & $25 \%$ \\
\hline \multicolumn{2}{|c|}{ Jumlah } & 20 & $100 \%$ \\
\hline
\end{tabular}

Tabel 9. Berperan aktif dalam pelajaran bahasa Arab (angket item 9)

Tabel di atas menunjukkan bahwa 5\% peserta didik menyatakan berperan aktif dalam pelajaran bahasa Arab, peserta didik yang menyatakan sering sebanyak 40\%, peserta didik yang menyatakan kadang-kadang sebanyak 30\%, dan peserta didik yang menyatakan tidak 


\section{Loghat Arabi: Jurnal Bahasa Arab dan Pendidikan Bahasa Arab}

pernah sebanyak 25\%. Dari tabel tersebut dapat disimpulkan bahwa peserta didik sering berperan aktif dalam pelajaran bahasa Arab.

\begin{tabular}{|c|l|c|c|}
\hline No & Alternatif Jawaban & N & \% \\
\hline 1 & Selalu & - & $0 \%$ \\
\hline 2 & Sering & 8 & $40 \%$ \\
\hline 3 & Kadang-kadang & 10 & $50 \%$ \\
\hline 4 & Tidak pernah & 2 & $10 \%$ \\
\hline \multicolumn{2}{|c|}{ Jumlah } & 20 & $100 \%$ \\
\hline
\end{tabular}

Tabel 10. Aktif dalam kegiatan diskusi di dalam kelas (angket item 10)

Tabel di atas menunjukkan bahwa $0 \%$ peserta didik menyatakan aktif dalam kegiatan diskusi di dalam kelas, peserta didik yang menyatakan sering sebanyak 40\%, peserta didik yang menyatakan kadang-kadang sebanyak 50\%, dan peserta didik yang menyatakan tidak pernah sebanyak 10\%. Dari tabel tersebut dapat disimpulkan bahwa peserta didik kadangkadang aktif dalam kegiatan diskusi di dalam kelas.

\begin{tabular}{|c|l|c|c|}
\hline No & Alternatif Jawaban & N & \% \\
\hline 1 & Selalu & - & $0 \%$ \\
\hline 2 & Sering & 7 & $35 \%$ \\
\hline 3 & Kadang-kadang & 9 & $45 \%$ \\
\hline 4 & Tidak pernah & 4 & $20 \%$ \\
\hline \multicolumn{2}{|c|}{ Jumlah } & 20 & $100 \%$ \\
\hline
\end{tabular}

Tabel 11. Tidak takut mengeluarkan pendapat dalam pelajaran bahasa Arab (angket item 11)

Tabel di atas menunjukkan bahwa $0 \%$ peserta didik menyatakan tidak takut mengeluarkan pendapat dalam pelajaran bahasa Arab, peserta didik yang menyatakan sering sebanyak 35\%, peserta didik yang menyatakan kadang-kadang sebanyak 45\%, dan peserta didik yang menyatakan tidak pernah sebanyak 20\%. Dari tabel tersebut dapat disimpulkan bahwa peserta didik kadang-kadang tidak takut mengeluarkan pendapat dalam pelajaran bahasa Arab.

\begin{tabular}{|c|l|c|c|}
\hline No & Alternatif Jawaban & N & \% \\
\hline 1 & Selalu & - & $0 \%$ \\
\hline 2 & Sering & 7 & $35 \%$ \\
\hline 3 & Kadang-kadang & 10 & $50 \%$ \\
\hline 4 & Tidak pernah & 3 & $15 \%$ \\
\hline \multicolumn{2}{|c|}{ Jumlah } & 20 & $100 \%$ \\
\hline
\end{tabular}

Tabel 12. Tetap belajar walaupun tidak ada ujian (angket item 12) 


\section{Loghat Arabi: Jurnal Bahasa Arab dan Pendidikan Bahasa Arab}

Tabel di atas menunjukkan bahwa $0 \%$ peserta didik menyatakan tetap belajar walaupun tidak ada ujian, peserta didik yang menyatakan sering sebanyak 35\%, peserta didik yang menyatakan kadang-kadang sebanyak 50\%, dan peserta didik yang menyatakan tidak pernah sebanyak 15\%. Dari tabel tersebut dapat disimpulkan bahwa peserta didik kadangkadang tetap belajar walaupun tidak ada ujian.

\begin{tabular}{|c|l|c|c|}
\hline No & Alternatif Jawaban & N & \% \\
\hline 1 & Selalu & - & $0 \%$ \\
\hline 2 & Sering & 9 & $45 \%$ \\
\hline 3 & Kadang-kadang & 8 & $40 \%$ \\
\hline 4 & Tidak pernah & 3 & $15 \%$ \\
\hline \multicolumn{2}{|c|}{ Jumlah } & 20 & $100 \%$ \\
\hline
\end{tabular}

Tabel 13. Mengikuti kegiatan yang berhubungan dengan bahasa Arab diluar sekolah (angket item 13)

Tabel di atas menunjukkan bahwa $0 \%$ peserta didik menyatakan mengikuti kegiatan yang berhubungan dengan bahasa Arab diluar sekolah, peserta didik yang menyatakan sering sebanyak $45 \%$, peserta didik yang menyatakan kadang-kadang sebanyak $40 \%$, dan peserta didik yang menyatakan tidak pernah sebanyak 15\%. Dari tabel tersebut dapat disimpulkan bahwa peserta didik sering mengikuti kegiatan yang berhubungan dengan bahasa Arab diluar sekolah.

\begin{tabular}{|c|l|c|c|}
\hline No & Alternatif Jawaban & N & \% \\
\hline 1 & Selalu & - & $0 \%$ \\
\hline 2 & Sering & 10 & $50 \%$ \\
\hline 3 & Kadang-kadang & 5 & $25 \%$ \\
\hline 4 & Tidak pernah & 5 & $25 \%$ \\
\hline \multicolumn{2}{|c|}{ Jumlah } & 20 & $100 \%$ \\
\hline
\end{tabular}

Tabel 14. Mengulangi pelajaran bahasa Arab dirumah (angket item 14)

Tabel di atas menunjukkan bahwa $0 \%$ peserta didik menyatakan mengulangi pelajaran bahasa Arab dirumah, peserta didik yang menyatakan sering sebanyak 50\%, peserta didik yang menyatakan kadang-kadang sebanyak $25 \%$, dan peserta didik yang menyatakan tidak pernah sebanyak 25\%. Dari tabel tersebut dapat disimpulkan bahwa peserta didik sering mengulangi pelajaran bahasa Arab dirumah.

\begin{tabular}{|c|l|c|c|}
\hline No & \multicolumn{1}{|c|}{ Alternatif Jawaban } & N & \% \\
\hline 1 & Selalu & 4 & $20 \%$ \\
\hline 2 & Sering & 3 & $15 \%$ \\
\hline
\end{tabular}




\section{Loghat Arabi: Jurnal Bahasa Arab dan Pendidikan Bahasa Arab}

\begin{tabular}{|c|l|c|c|}
\hline 3 & Kadang-kadang & 7 & $35 \%$ \\
\hline 4 & Tidak pernah & 6 & $30 \%$ \\
\hline \multicolumn{2}{|c|}{ Jumlah } & 20 & $100 \%$ \\
\hline
\end{tabular}

Tabel 15. Rajin membaca buku-buku bahasa Arab (angket item 15)

Tabel di atas menunjukkan bahwa $20 \%$ peserta didik menyatakan rajin membaca buku-buku bahasa Arab, peserta didik yang menyatakan sering sebanyak 15\%, peserta didik yang menyatakan kadang-kadang sebanyak 35\%, dan peserta didik yang menyatakan tidak pernah sebanyak 30\%. Dari tabel tersebut dapat disimpulkan bahwa peserta didik kadangkadang rajin membaca buku-buku bahasa Arab.

\begin{tabular}{|c|l|c|c|}
\hline No & Alternatif Jawaban & N & \% \\
\hline 1 & Selalu & - & $0 \%$ \\
\hline 2 & Sering & 9 & $45 \%$ \\
\hline 3 & Kadang-kadang & 8 & $40 \%$ \\
\hline 4 & Tidak pernah & 3 & $15 \%$ \\
\hline \multicolumn{2}{|c|}{ Jumlah } & 20 & $100 \%$ \\
\hline
\end{tabular}

Tabel 16. Membaca buku bahasa Arab untuk menjamin nilai rapor tinggi (angket item 16)

Tabel di atas menunjukkan bahwa $0 \%$ peserta didik menyatakan membaca buku-buku bahasa Arab untuk menjamin nilai raport tinggi, peserta didik yang menyatakan sering sebanyak $45 \%$, peserta didik yang menyatakan kadang-kadang sebanyak 40\%, dan peserta didik yang menyatakan tidak pernah sebanyak 15\%. Dari tabel tersebut dapat disimpulkan bahwa peserta didik sering membaca buku bahasa Arab untuk menjamin nilai rapor tinggi.

\begin{tabular}{|c|l|c|c|}
\hline No & Alternatif Jawaban & N & \% \\
\hline 1 & Selalu & 6 & $30 \%$ \\
\hline 2 & Sering & 8 & $40 \%$ \\
\hline 3 & Kadang-kadang & 6 & $30 \%$ \\
\hline 4 & Tidak pernah & - & $0 \%$ \\
\hline \multicolumn{2}{|c|}{ Jumlah } & 20 & $100 \%$ \\
\hline
\end{tabular}

Tabel 17. Senang bila guru bahasa Arab memberi pekerjaan rumah (angket item 17)

Tabel di atas menunjukkan bahwa $30 \%$ peserta didik menyatakan senang bila guru bahasa Arab memberi pekerjaan rumah, peserta didik yang menyatakan sering sebanyak 40\%, peserta didik yang menyatakan kadang-kadang sebanyak 30\%, dan peserta didik yang menyatakan tidak pernah sebanyak 0\%. Dari tabel tersebut dapat disimpulkan bahwa peserta didik sering senang bila guru bahasa Arab memberi pekerjaan rumah. 


\section{Loghat Arabi: Jurnal Bahasa Arab dan Pendidikan Bahasa Arab}

\begin{tabular}{|c|l|c|c|}
\hline No & Alternatif Jawaban & N & \% \\
\hline 1 & Selalu & 1 & $5 \%$ \\
\hline 2 & Sering & 2 & $10 \%$ \\
\hline 3 & Kadang-kadang & 9 & $45 \%$ \\
\hline 4 & Tidak pernah & 8 & $40 \%$ \\
\hline \multicolumn{2}{|c|}{ Jumlah } & 20 & $100 \%$ \\
\hline
\end{tabular}

Tabel 18. Siap bila guru bahasa Arab memberikan ulangan mendadak (angket item 18)

Tabel di atas menunjukkan bahwa 5\% peserta didik menyatakan siap bila guru bahasa Arab memberikan ulangan mendadak, peserta didik yang menyatakan sering sebanyak $10 \%$, peserta didik yang menyatakan kadang-kadang sebanyak $45 \%$, dan peserta didik yang menyatakan tidak pernah sebanyak 40\%. Dari tabel tersebut dapat disimpulkan bahwa peserta didik kadang-kadang siap bila guru bahasa Arab memberikan ulangan mendadak.

\begin{tabular}{|c|l|c|c|}
\hline No & Alternatif Jawaban & N & \% \\
\hline 1 & Selalu & - & $0 \%$ \\
\hline 2 & Sering & 12 & $60 \%$ \\
\hline 3 & Kadang-kadang & 8 & $40 \%$ \\
\hline 4 & Tidak pernah & - & $0 \%$ \\
\hline \multicolumn{2}{|c|}{ Jumlah } & 20 & $100 \%$ \\
\hline
\end{tabular}

Tabel 19. Mencatat hal-hal yang penting walaupun guru bahasa Arab tidak memerintahkan ketika guru bahasa Arab menyampaikan materi (angket item 19)

Tabel di atas menunjukkan bahwa $0 \%$ peserta didik menyatakan mencatat hal-hal yang penting walaupun guru bahasa Arab tidak memerintahkan ketika guru bahasa Arab menyampaikan materi, peserta didik yang menyatakan sering sebanyak $60 \%$, peserta didik yang menyatakan kadang-kadang sebanyak $40 \%$, dan peserta didik yang menyatakan tidak pernah sebanyak 0\%. Dari tabel tersebut dapat disimpulkan bahwa peserta didik sering mencatat hal-hal yang penting walaupun guru bahasa Arab tidak memerintahkan ketika guru bahasa Arab menyampaikan materi.

\begin{tabular}{|c|l|c|c|}
\hline No & Alternatif Jawaban & N & \% \\
\hline 1 & Selalu & - & $0 \%$ \\
\hline 2 & Sering & 7 & $35 \%$ \\
\hline 3 & Kadang-kadang & 9 & $45 \%$ \\
\hline 4 & Tidak pernah & 4 & $20 \%$ \\
\hline \multicolumn{2}{|c|}{ Jumlah } & 20 & $100 \%$ \\
\hline
\end{tabular}

Tabel 20. Mengetahui manfaat belajar bahasa Arab (angket item 20) 


\section{Loghat Arabi: Jurnal Bahasa Arab dan Pendidikan Bahasa Arab}

Tabel di atas menunjukkan bahwa $0 \%$ peserta didik menyatakan mengetahui manfaat belajarbahasa Arab, peserta didik yang menyatakan sering sebanyak 35\%, peserta didik yang menyatakan kadang-kadang sebanyak $45 \%$, dan peserta didik yang menyatakan tidak pernah sebanyak 20\%. Dari tabel tersebut dapat disimpulkan bahwa peserta didik kadang-kadang mengetahui manfaat belajar bahasa Arab.

Hasil dari 20 Item Angket yang disebar dapat disimpulkan di MIS Ma'arif Ambopadang Kecamatan Tubbi Taramanu Kabupaten Polewali Mandar menyatakan bahwa peserta didik: 1) sering cepat datang ke sekolah/madrasah jika hari itu ada pelajaran bahasa Arab; 2) sering membawa buku paket bahasa Arab ketika ada pelajaran bahasa Arab; 3) guru mata pelajaran bahasa Arab sering menyenangkan; 4) sering betah di kelas ketika pelajaran bahasa Arab berlangsung; 5) kadang-kadang duduk di depan ketika pelajaran bahasa Arab berlangsung; 6) kadang-kadang mengajukan pertanyaan jika tidak mengerti pada pelajaran bahasa Arab; 7) selalu tidak suka diganggu ketika pelajaran bahasa Arab berlangsung; 8) sering konsentrasi mendengar dan memperhatikan penjelasan guru bahasa Arab; 9) sering berperan aktif dalam pelajaran bahasa Arab; 10) kadang-kadang aktif dalam kegiatan diskusi di dalam kelas; 11) kadang-kadang tidak takut mengeluarkan pendapat dalam pelajaran bahasa Arab; 12) kadang-kadang tetap belajar walaupun tidak ada ujian; 13) sering mengikuti kegiatan yang berhubungan dengan bahasa Arab diluar sekolah; 15) mengulangi pelajaran bahasa Arab dirumah; 16) kadang-kadang rajin membaca buku-buku bahasa Arab; 17) sering senang bila guru bahasa Arab memberi pekerjaan rumah; 18) kadang-kadang siap bila guru bahasa Arab memberikan ulangan mendadak 19) sering mencatat hal-hal yang penting walaupun guru bahasa Arab tidak memerintahkan ketika guru bahasa Arab menyampaikan materi; 20) kadang-kadang mengetahui manfaat belajar bahasa Arab.peserta didik kadang-kadang mengetahui manfaat belajarbahasa Arab.

\section{Gambaran Pengaruh Minat Belajar Terhadap Hasil Belajar Peserta Didik Pada Mata Pelajaran Bahasa Arab Pada MIS Ma'arif Ambopadang Kecamatan Tubbi Taramanu Kabupaten Polewali Mandar}

Dalam penelitian ini minat belajar merupakan variabel pertama yaitu variabel $X$ yang merupakan independen variabel. Pengumpulan data variabel ini dilakukan dengan penyebaran angket kepada peserta didik MIS Ma'arif Ambopadang Kecamatan Tubbi Taramanu Kabupaten Polewali Mandar. 


\section{Loghat Arabi: Jurnal Bahasa Arab dan Pendidikan Bahasa Arab}

Adapun data minat belajar peserta didik MIS Ma'arif Ambopadang Kecamatan Tubbi Taramanu dideskripsikan melali angket yang disebarkan pada 20 Responden di MIS Ma'arif Ambopadang Kecamatan Tubbi Taramanu Kabupaten Polewali Mandar.

Sedangkan, hasil belajar merupakan variabel kedua yaitu variabel Y yang merupakan dependen variabel. Pengumpulan data variabel ini dilakukan dengan tes peserta didik MIS Ma'arif Ambopadang Kecamatan Tubbi Taramanu.

Agar data dapat dengan mudah dibaca dan diinterpretasikan maka peneliti menggunakan rumus product moment. Peneliti menggunakan statistik product moment karena dalam penelitian ini terdapat dua variabel yang perlu mendapat kejelasan, apakah terdapat pengaruh variabel $\mathrm{X}$ terhadap Variabel $\mathrm{Y}$ atau tidak terdapat pengaruh. Kedua variabel tersebut adalah minat balajar dan hasil belajar pada mata pelajaran Bahasa Arab.

\begin{tabular}{|c|l|c|c|c|}
\hline No & Nama & Kelas & Hasil Angket & Hasil tes \\
\hline 1 & R1 & III & 54 & 80 \\
\hline 2 & R2 & III & 49 & 77 \\
\hline 3 & R3 & III & 44 & 85 \\
\hline 4 & R4 & III & 44 & 66 \\
\hline 5 & R5 & IV & 44 & 73 \\
\hline 6 & R6 & IV & 59 & 91 \\
\hline 7 & R7 & IV & 53 & 77 \\
\hline 8 & R8 & IV & 44 & 65 \\
\hline 9 & R9 & IV & 55 & 81 \\
\hline 10 & R10 & IV & 52 & 76 \\
\hline 11 & R11 & V & 46 & 75 \\
\hline 12 & R12 & V & 42 & 75 \\
\hline 13 & R13 & V & 47 & 84 \\
\hline 14 & R14 & V & 41 & 80 \\
\hline 15 & R15 & VI & 46 & 69 \\
\hline 16 & R16 & VI & 44 & 73 \\
\hline 17 & R17 & VI & 47 & 71 \\
\hline 18 & R18 & VI & 55 & 85 \\
\hline 19 & R19 & VI & 52 & 71 \\
\hline 20 & R20 & VI & 49 & 78 \\
\hline & & & $\mathbf{9 6 7}$ & $\mathbf{1 5 3 2}$ \\
\hline
\end{tabular}

Tabel 21. Hasil Angket dan Hasil Tes Peserta Didik MIS Ma'arif Ambopadang

\begin{tabular}{|c|c|c|c|c|c|}
\hline No & $\mathbf{X}$ & $\mathbf{Y}$ & $\mathbf{X Y}$ & $\mathbf{X}^{\mathbf{2}}$ & $\mathbf{Y}^{\mathbf{2}}$ \\
\hline 1 & 54 & 80 & 4320 & 2916 & 6400 \\
\hline 2 & 49 & 77 & 3773 & 2401 & 5929 \\
\hline
\end{tabular}


Loghat Arabi: Jurnal Bahasa Arab dan Pendidikan Bahasa Arab

\begin{tabular}{|c|c|c|c|c|c|}
\hline 3 & 44 & 85 & 3740 & 1936 & 7225 \\
\hline 4 & 44 & 66 & 2904 & 1936 & 4356 \\
\hline 5 & 44 & 73 & 3212 & 1936 & 5329 \\
\hline 6 & 59 & 91 & 5369 & 3481 & 8281 \\
\hline 7 & 53 & 77 & 4081 & 2809 & 5929 \\
\hline 8 & 44 & 65 & 2860 & 1936 & 4225 \\
\hline 9 & 55 & 81 & 4455 & 3025 & 6561 \\
\hline 10 & 52 & 76 & 3952 & 2704 & 5776 \\
\hline 11 & 46 & 75 & 3450 & 2116 & 5625 \\
\hline 12 & 42 & 75 & 3150 & 1764 & 5625 \\
\hline 13 & 47 & 84 & 3948 & 2209 & 7056 \\
\hline 14 & 41 & 80 & 3280 & 1681 & 6400 \\
\hline 15 & 46 & 69 & 3174 & 2116 & 4761 \\
\hline 16 & 44 & 73 & 3212 & 1936 & 5329 \\
\hline 17 & 47 & 71 & 3337 & 2209 & 5041 \\
\hline 18 & 55 & 85 & 4675 & 3025 & 7225 \\
\hline 19 & 52 & 71 & 3692 & 2704 & 5041 \\
\hline 20 & 49 & 78 & 3822 & 2401 & 6084 \\
\hline Jumlah & $\mathbf{9 6 7}$ & $\mathbf{1 5 3 2}$ & $\mathbf{7 4 4 0 6}$ & $\mathbf{4 7 2 4 1}$ & $\mathbf{1 1 8 1 9 8}$ \\
\hline
\end{tabular}

Tabel 21. Perhitungan Angka Indeks Korelasi antara Variabel X (Minat Belajar) dan Variabel Y (Hasil Belajar) Mata Pelajaran Bahasa Arab

Dari tabel di atas diketahui data sebagai berikut:

$$
\begin{aligned}
& \Sigma \mathrm{N}=20 \\
& \Sigma \mathrm{X}=967 \\
& \Sigma x y=74406 \\
& \Sigma \mathrm{Y}=1532 \\
& \Sigma X^{2}=47241 \\
& \Gamma x y=\quad \mathrm{N} \Sigma \mathrm{XY}-(\Sigma \mathrm{X})(\Sigma \mathrm{Y}) \\
& {\left[\mathrm{N} \Sigma \mathrm{X}^{2} \sqrt{\left.-(\Sigma \mathrm{X})^{2}\right]\left[\mathrm{N} \Sigma \mathrm{Y}^{2}-(\Sigma \mathrm{Y})^{2}\right]}\right.} \\
& \Gamma x y=20 \times 74406-(967 \times 1532) \\
& {\left[20 \times \sqrt{\left.47241-(967)^{2}\right]\left[20 \times 118198-(1532)^{2}\right]}\right.} \\
& \Gamma x y=\frac{1488120-1481444}{[9 \sqrt{4820-935089][2363960-2347024]}} \\
& =\frac{6676}{(97 \sqrt{1 \times 16936)}} \\
& =\frac{6676}{164804216} \\
& =\frac{6676}{12837,6}
\end{aligned}
$$




$$
=0,520
$$

Setelah dilakukan perhitungan secara keseluruhan, diperoleh hasil antara variabel X (Minat Belajar) dan variabel Y (Hasil Belajar) diperoleh angka " $\Gamma$ " product moment sebesar 0,520 .

Selanjutnya setelah melakukan perhitungan, langkah berikutnya adalah memberikan interpretasi dengan menggunakan tabel nilai " $r$ " :

$$
\text { df }=\mathrm{N}-\mathrm{nr}=\mathbf{2 0}-\mathbf{2}=\mathbf{1 8}
$$

Dengan memeriksa tabel nilai "r" product moment, ternyata df sebesar 18. Pada taraf signifikan 5\% $\mathrm{r}_{\text {tabel }}=0,468$; sedangkan pada taraf signifikan $1 \%$ diperoleh $\mathrm{r}_{\text {tabel }}=0,590$. Maka diperoleh hasil $\mathrm{r}$ hitung lebih besar baik pada taraf sinifikasi $5 \%(0,520>0,468)$ pada taraf sinifikasi $1 \%(0,520>0,01)$. Dengan demikian dapat diketahui, hipotesis nihil (Ho) ditolak sedangkan hipotesis alternatif (Ha) diterima. Dari perhitungan ini berarti menunjukkan terdapat pengaruh yang signifikan antara minat belajar dan hasil belajar peserta didik pada mata pelajaran bahasa Arab.

Setelah melakukan uji hipotesis untuk mengetahui seberapa besar pengaruh variabel X terhadap variabel $\mathrm{Y}$ yang dinyatakan dalam bentuk persen, maka digunakan rumus “Coeficient of Determination" atau koefisien penentu yang dalam hal ini digunakan untuk lebih memudahkan pemberian interpretasi angka indeks korelasi " $r$ " product moment di atas sebagai berikut:

$$
\begin{aligned}
\mathrm{KD} & =\mathrm{r}^{2} \times 100 \% \\
& =0,520 \times 100 \% \\
& =0,2704 \times 100 \% \\
& =27,04 \%
\end{aligned}
$$

Menghitung koefisien determinan di maksudkan untuk mengetahui besarnya pengaruh minat belajar terhadap hasil belajar peserta didik pada mata pelajaran bahasa Arab pada MIS Ma'arif Ambopadang Kecamatan Tubbi Taramanu Kabupaten Polewali Mandar. Dari perhitungan di atas diperoleh hasil koefisien determinan sebesar 27,04\% dan menunjukkan bahwa 72,96\% dari hasil belajar peserta didik dipengaruhi oleh faktor lain. Faktor-faktor tersebut kemungkinan dapat juga disebabkan oleh faktor internal atau faktor eksternal peserta didik.

Setelah dilakukannya pengujian hipotesis, diperoleh hasil hipotesis nihil (Ho) yang diajukan ditolak dan hipotesis alternatif $(\mathrm{Ha})$ diterima yang berarti adanya pengaruh minat 


\section{Loghat Arabi: Jurnal Bahasa Arab dan Pendidikan Bahasa Arab}

belajar terhadap hasil belajar peserta didik pada mata pelajaran Bahasa Arab yang dapat diketahui dari angket.

Minat merupakan kecenderungan untuk selalu memperhatikan dan mengingat sesuatu secara terus menerus. Minat sangat erat kaitannya dengan perasaan terutama perasaan senang. Karena itu dapat dikatakan minat itu terjadi karena sikap senang kepada sesuatu. Orang yang berminat terhadap sesuatu berarti sikapnya senang terhadap sesuatu itu. ${ }^{12}$

Faktor internal yang mempengaruhi minat belajar adalah faktor psikis, yaitu kondisi kejiwaan yang berkaitan dengan perasaan atau emosi, motivasi, bakat, inteligensi, dan kemampuan dasar dalam suatu bidang tertentu. Faktor psikis juga dapat dipengaruhi oleh keyakinan realistis di kalangan peserta dalam mempelajari bahasa Arab sebagai bahasa asing. $^{13}$

Faktor eksternal yang mempengaruhi minat belajar adalah lingkungan sosial dan lingkungan non sosial, lingkungan sosial berupa lingkungan keluarga, lingkungan sekolah maupun lingkungan masyarakat. Sedangkan lingkungan non sosial berupa gedung sekolah dan letaknya, rumah tempat tinggal keluarga siswa dan letaknya, alat-alat belajar, keadaan cuaca dan waktu yang digunakan siswa. ${ }^{14}$

Faktor penghambat hasil belajar yaitu kurangnya buku-buku yang disediakan oleh sekolah untuk menunjang dan menambah wawasan peserta didik, kurangnya motivasi yang diberikan oleh guru dan orang tua peserta didik dalam meningkatkan hasil belajar serta fasilitas sarana dan prasarana sekolah yang kurang memadai. ${ }^{15}$

Usaha yang dilakukan oleh guru mata pelajaran Bahasa Arab dalam menanggulangi hambatan kurangnya minat belajar peserta didik untuk meningkatkan hasil belajar adalah dengan metode yang dilakukan pada saat proses pembelajaran dibuat semenarik mungkin seperti dengan belajar sambil bermain, memberikan hadiah untuk peserta didik yang rajin dan berprestasi dalam mata pelajaran bahasa Arab. ${ }^{16}$ Guru sebagai kunci keberhasilan dan keefektifan sebuah pembelajaran. Guru tidak hanya dapat mentransfer informasi dan

\footnotetext{
12 Muhibbin Syah, Psikologi Pendidikan: Suatu Pendekatan Baru (Bandung: Remaja Rosda Karya, 1996), h. 130.

13 Jusoh, Zailani, and Liza Abdullah. "ESL Student Teachers Beliefs about Learning Arabic as a Foreign Language." International Journal of Asian Social Science 10.1 (2020): 43-50. http://www.aessweb.com/journals/January2020/5007/4830

${ }^{14}$ Alisuf Sabri, Psikologi Pendidikan, (Jakarta: Pedoman Ilmu Jaya, 2007), h. 84.

${ }^{15}$ Hasil Wawancara dengan Guru Mata Pelajaran Bahasa Arab MIS Ma'arif Ambopadang Kecamatan Tubbi Taramanu, pada Hari Sabtu 12 Desember 2020 pukul 10.20 wita

${ }^{16}$ Hasil Wawancara dengan Guru Mata Pelajaran Bahasa Arab MIS Ma'arif Ambopadang Kecamatan Tubbi Taramanu, pada Hari Sabtu 12 Desember 2020 pukul 10.20 wita
} 


\section{Loghat Arabi: Jurnal Bahasa Arab dan Pendidikan Bahasa Arab}

pengetahuan di kelas melainkan juga menjadi tenaga pendidik untuk mengasah soft skill peserta didik sekaligus memotivasinya untuk mendongkrak semangat dirinya agar mau belajar dan belajar melakukan, sehingga pembelajaran menjadi hidup, aktif, interaktif dan efektif. ${ }^{17}$

Berdasarkan faktor-faktor tersebut di atas, dapat dilihat bahwa teori dan realita yang terjadi yaitu minat belajar cukup mempengaruhi hasil belajar peserta didik. Perhitungan hasil koefisien determinan di atas menunjukkan bahwa variabel $\mathrm{X}$ (minat belajar) telah memberikan pengaruh terhadap variabel Y (hasil belajar) sebesar 27,04\%\% dan 72,96\% dari hasil belajar dipengaruhi oleh faktor lain yang kemungkinan merupakan faktor internal atau eksternal. Faktor internal yaitu faktor yang berasal dari dalam diri seseorang seperti sifat, bakat, keturunan dan sebagainya. Sedangkan faktor eksternal yaitu faktor yang berada di luar diri seseorang yang dapat mempengaruhi mental seseorang. Faktor eksternal yang paling dekat dengan seorang manusia adalah keluarga, sekolah dan masyarakat.

Berdasarkan uraian di atas, maka peneliti dapat memberi menyimpulkan bahwa tujuan penelitian ini sesuai dengan hipotesisnya maka terdapat pengaruh yang sedang atau cukup terhadap hasil belajar peserta didik pada mata pelajaran Bahasa Arab di MIS Ma'arif Ambopadang Kecamatan Tubbi Taramanu. Ini dapat dilihat dari hasil $r_{\text {hitung }}$ lebih besar dari $\mathrm{r}_{\text {tabel }}$ dalam taraf signifikan $5 \%(0,520>0,468)$ dan taraf sinifikasi $1 \%(0,520>0,01)$. Dengan ini hipotesis diterima semakin peserta didik memiliki minat belajar yang tinggi maka semakin baik hasil belajar peserta didik dalam belajar.

Hasil penelitian ini berkaitan dengan penelitian sebelumnya yang dikemukakan oleh Dinar Tiara Nadip Putri dan Gatot Isnani dalam jurnalnya yang berjudul "Pengaruh Minat dan Motivasi terhadap Hasil Belajar pada Mata Pelajaran Pengantar Administrasi Perkantoran" yang menarik kesimpulan bahwa terdapat pengaruh positif yang signifikan antara minat terhadap hasil belajar dengan persentasi sebesar 5,94\% dan tidak ada pengaruh positif yang signifikan antara motivasi terhadap hasil belajar. Minat merupakan variabel yang dominan mempengaruhi hasil belajar. ${ }^{18}$

Hasil penelitian lain juga menyimpulkan bahwa terdapat pengaruh sumber belajar terhadap minat belajar Bahasa Arab. Hal ini dapat dilihat dari hasil analisis data dengan

${ }^{17}$ Mahmud, Basri, and Hamzah Hamzah. "Pembelajaran Efektif dalam Pengajaran Bahasa Arab Tingkat Menengah." Loghat Arabi: Jurnal Bahasa Arab dan Pendidikan Bahasa Arab 1.1 (2020): 23-36. https://journal.iaiddipolman.ac.id/index.php/loghat/article/view/3

18 Abdul Rohim, Pengaruh Minat Belajar terhadap Prestasi Belajar Siswa pada Bidang Studi PAI' Skripsi (Jakarta: Fak. Ilmu Tarbiyah dan Keguruan UIN Syarif Hidayatullah Jakarta, 2011), http://repository.uinjkt.ac.id//dspace/handle/123456789/357 (diakses pada tanggal 10 Juli, 2020). 


\section{Loghat Arabi: Jurnal Bahasa Arab dan Pendidikan Bahasa Arab}

menggunakan rumus regresi sederhana dan mendapatkan nilai. ${ }^{19}$ Hal ini pun memperkuat bahwasanya memang terdapat hubungan antara minat belajar dan hasil belajar.

Hasil penelitian ini juga sejalan dengan pendapat yang dikemukakan oleh M. Dalyono dalam bukunya "Psikologi Pendidikan" mengatakan bahwa minat yang besar terhadap sesuatu merupakan modal yang besar artinya untuk mencapai/memperoleh benda atau tujuan yang diminati itu. Pada umumnya minat seseorang terhadap sesuatu akan diekspresikan melalui kegiatan atau aktivitas yang berkaitan dengan minatnya. Siswa yang memiliki minat tinggi akan senantiasa memberikan perhatian penuh dalam usahanya mencapai tujuan. Hal-hal yang menarik dan berguna bagi kehidupan serta hal-hal yang berhubungan dengan bahan pelajaran yang sedang dipelajari dapat membantu dalam meningkatkan minat siswa. ${ }^{20}$

\section{PENUTUP}

Berdasarkan pembahasan di atas tentang penelitian ini, yaitu tentang pengaruh minat belajar terhadap hasil belajar peserta didik pada mata pelajaran Bahasa Arab pada MIS Ma'arif Ambopadang Kecamatan Tubbi Taramanu, maka dapat disimpulkan bahwa:

1. Minat belajar peserta didik terhadap mata pelajaran Bahasa Arab pada MIS Ma'arif Ambopadang Kecamatan Tubbi Taramanu tergolong cukup baik

2. Terdapat pengaruh minat belajar yang sedang atau cukup terhadap hasil belajar peserta didik pada mata pelajaran bahasa Arab pada MIS Ma'arif Ambopadang Kecamatan Tubbi Taramanu. Hal ini dapat dilihat dari data yang diperoleh hasil $\mathrm{r}_{\text {hitung }}$ lebih besar baik pada taraf sinifikasi $5 \%(0,520>0,468)$ maupun pada taraf sinifikasi $1 \%(0,520>$ $0,01)$.

Adapun implikasi dari penelitian ini bahwasanya peneliti berharap kepada semua yang berkecimpung di dunia pendidikan agar senantiasa hasil penelitian ini memiliki makna akademik yang dapat menambah informasi dan memperkaya khazanah intelektual baik dari pendidik maupun peserta didik khususnya peserta didik MIS Ma'arif Ambopadang Kecamatan Tubbi Taramanu. Selain itu, peneliti juga berharap kepada guru, dalam mengajar materi pelajaran bahasa Arab hendaknya bisa dijadikan sebagai bahan acuan dan rujukan dalam proses pembelajaran. Terakhir, peneliti juga berharap kepada

${ }^{19}$ Suryani, Erma, and Ayu Wahyuni. "Pengaruh Sumber Belajar Terhadap Minat Belajar Bahasa Arab Siswa Kelas VII MTs Negeri 2 Sumbawa Kabupaten Sumbawa Besar." El-Tsaqafah: Jurnal Jurusan PBA 17.1 (2018): 1-15. https://journal.uinmataram.ac.id/index.php/eltsaqafah/article/view/474

${ }^{20}$ M. Dalyono, Psikologi Pendidikan, (Jakarta: Rineka Cipta, 2009) h. 56. 


\section{Loghat Arabi: Jurnal Bahasa Arab dan Pendidikan Bahasa Arab}

peneliti berikutnya, agar dapat mengembangkan penelitian ini. Dalam artian penelitian ini hanya meneliti dari sudut pandang minat belajar peserta didik dan hasil belajar peserta didik pada mata pelajaran bahasa Arab saja, maka para peneliti berikutnya dapat melakukan penelitian dari sudut pandang yang lain.

\section{Daftar Pustaka}

Abdul Rohim, Pengaruh Minat Belajar terhadap Prestasi Belajar Siswa pada Bidang Studi PAI" Skripsi (Jakarta: Fak. Ilmu Tarbiyah dan Keguruan UIN Syarif Hidayatullah Jakarta, 2011), http://repository.uinjkt.ac.id//dspace/handle/123456789/357 (diakses pada tanggal 10 Juli, 2020).

AH, Hanifal Fauzy, Zainal Abidin Arief, and Muhyani Muhyani. "Strategi motivasi belajar dan minat belajar dengan hasil belajar Bahasa Arab." Tawazun: Jurnal Pendidikan Islam $\quad 12.1 \quad$ (2019): $112-127 . \quad$ http://ejournal.uikabogor.ac.id/index.php/TAWAZUN/article/view/1843

Akmaliyah, Akmaliyah, et al. "Child-Friendly Teaching Approach for Arabic Language in Indonesian Islamic Boarding School." International Journal of Language Education 5.1 (2021): 501-514. https://ojs.unm.ac.id/ijole/article/view/15297

Dalyono, M. Psikologi Pendidikan. Jakarta: Rineka Cipta, 2009.

Hamzah, Hamzah. "KONSTRUKTIVISME DAN IMPLIKASINYA DALAM PEMBELAJARAN BAHASA ARAB." Prosiding Konferensi Nasional Bahasa Arab $4.4 \quad$ (2018): 117-128. http://prosiding.arabum.com/index.php/konasbara/article/view/262

Hasil Wawancara dengan Guru Mata Pelajaran Bahasa Arab MIS Ma'arif Ambopadang Kecamatan Tubbi Taramanu, pada Hari Sabtu 12 Desember 2020 pukul 10.20 wita

Hasil Wawancara dengan Guru Mata Pelajaran Bahasa Arab MIS Ma'arif Ambopadang Kecamatan Tubbi Taramanu, pada Hari Sabtu 12 Desember 2020 pukul 10.20 wita

Jusoh, Zailani, and Liza Abdullah. "ESL Student Teachers Beliefs about Learning Arabic as a Foreign Language." International Journal of Asian Social Science 10.1 (2020): 43-50. http://www.aessweb.com/journals/January2020/5007/4830

Mahmud, Basri, and Hamzah Hamzah. "Pembelajaran Efektif dalam Pengajaran Bahasa Arab Tingkat Menengah." Loghat Arabi: Jurnal Bahasa Arab dan Pendidikan Bahasa Arab $1.1 \quad$ 23-36. https://journal.iaiddipolman.ac.id/index.php/loghat/article/view/3

Munawarah, Munawarah, and Zulkiflih Zulkiflih. "Pembelajaran Keterampilan Menulis (Maharah al-Kitabah) dalam Bahasa Arab." Loghat Arabi: Jurnal Bahasa Arab dan $\begin{array}{lllll}\text { Pendidikan Bahasa } & \text { Arab 22-34. }\end{array}$ https://journal.iaiddipolman.ac.id/index.php/loghat/article/view/15 


\section{Loghat Arabi: Jurnal Bahasa Arab dan Pendidikan Bahasa Arab}

Mustafa, Mustafa. "Dinamika Metode Pembelajaran Bahasa Arab." Loghat Arabi: Jurnal Bahasa Arab dan Pendidikan Bahasa Arab 1.2 (2021): 56-71. https://journal.iaiddipolman.ac.id/index.php/loghat/article/view/17

Nugrawiyati, Jepri. "Media Audio-Visual dalam Pembelajaran Bahasa Arab." El-Wasathiya: $\begin{array}{lllll}\text { Jurnal Studi } & \text { Agama } & \text { 97-111. }\end{array}$ http://ejournal.kopertais4.or.id/mataraman/index.php/washatiya/article/view/3420

Putri, Wakhidati Nurrohmah. "Pengaruh Media Pembelajaran Terhadap Motivasi Belajar Bahasa Arab Siswa Madrasah Tsanawiyah." LISANIA: Journal of Arabic Education $\begin{array}{llll}\text { and } \quad \text { Literature } & \text { (2017): }\end{array}$ https://ijtihad.iainsalatiga.ac.id/index.php/lisania/article/view/1160/0

Pra Observasi (Di lakukan pada tanggal 13 Juni 2020)

Ritonga, Mahyudin, Hendro Widodo, and Talqis Nurdianto. "Arabic language learning reconstruction as a response to strengthen Al-Islam studies at higher education." Studies at Higher Education (January 23, 2021). International Journal of Evaluation and Research in Education (IJERE) 10.1 (2021): 355-363. https://papers.ssrn.com/sol3/papers.cfm?abstract_id=3791177

Sabri, Alisuf. Psikologi Pendidikan. Jakarta: Pedoman Ilmu Jaya, 2007.

Suryani, Erma, and Ayu Wahyuni. "Pengaruh Sumber Belajar Terhadap Minat Belajar Bahasa Arab Siswa Kelas VII MTs Negeri 2 Sumbawa Kabupaten Sumbawa Besar." ElTsaqafah: Jurnal Jurusan $\quad P B A \quad 17.1 \quad$ (2018): $1-15$. https://journal.uinmataram.ac.id/index.php/eltsaqafah/article/view/474

Syah, Muhibbin. Psikologi Pendidikan: Suatu Pendekatan Baru. Bandung: Remaja Rosda Karya, 1996.

. Psikologi Pendidikan dengan Pendekatan Baru. Cet. IX; Bandung: Remaja Rosda Karya, 2004. 
